\title{
PHILOSOPHICAL KNOWLEDGE IS THE METHODOLOGICAL REGULATOR FOR THE DEVELOPMENT OF ALL DISCIPLINES
}

\author{
Mamadaliev Muzaffar Umarovich \\ Senior teacher at the department "Philosophy" of Andizhan State University, Republic of Uzbekistan
}

Article DOI: https://doi.org/10.36713/epra4105

\begin{abstract}
The article depicts the nature of philosophic knowledge, their difference from the knowledge received from other subjects and its role in the process of formation of spiritually developed person.

KEY WORDS: Philosophical knowledge, natural knowledge, mysteries of the world, living education, intellectual eagerness, thinking absolutely, logical thinking, daily (ordinary) education (knowledge).
\end{abstract}

\section{INTRODUCTION}

It is not a secret that education is the basis of the ladder of development, the forage for thinking, the basis of worldview. Knowledge differed from man to animal, and language began to appear in its apparent and intimate socialization. In today's conditions where the level of knowledge of the person is increased and the possibilities for knowledge are increased, the importance of philosophical knowledge becomes even more important. After all, they are the means by which the general, special and professional knowledge is brought together and systematized. Even a student tired of philosophical lessons, debates, and analyzes relies on philosophical knowledge, without realizing it.

\section{METHODS}

The word "philosophy" was first used by Pythagoras, a Greek scholar of the sixth century BC. He asserted that only humans can love wisdom, and that true wisdom is the Creator. For some, learning the secrets of the world is boring, collecting wealth for another category, accumulating wealth is a hobby, and only some of them are familiar with the mysteries, wisdom, and historical heritage. Good deeds are often followed by rich, educated people. Fosil (that is, educated) and perfect (which means high spiritual and scholarly) are interested in philosophical knowledge. The science of epistemology, which examines the nature of knowledge, examines different types of knowledge (apart from knowledge and knowledge, emotional and everyday), and concludes that spirituality is all about knowledge, but most are scientific or philosophical knowledge.

\section{RESULTS AND DICSUSSIONS}

Philosophical knowledge is, therefore, necessary for all professionals and is taught at higher levels of education. In some countries, such as France, philosophy is taught at all levels of schools, colleges and universities. Philosophical knowledge, by its very nature, is a living knowledge, that is, it is essential in all aspects of life. To the Greater Socrates, a disciple called Timotheus asked, "Master, why don't you write this wonderful knowledge?" He replied, "O Timothy, you have faith in dead animal skin, and you have high confidence in living things" [1.p.59]. Formation of philosophical knowledge is an internal act that transmits other arguments. Thanks to this movement, an intellectual machine that requires intellectual courage is put into operation and a scientific picture is created from outside facts. For this reason, a worldview that is based on a single idea and revolves around it can only be achieved through teaching (with lectures and seminars). But frankly, in the process of teaching, you pour the opinions of some author to the listener.

A philosopher who is well-thought-out, makes logical conclusions, draws conclusions from rich material, cannot be prepared by lecturing and lecturing, or otherwise informing philosophy. The philosopher is born in controversial, deep meditation exercises. That is, we prepare a diploma who deserves to teach philosophy, but it's not fair to call him a philosopher in the literal sense. There are many talented philosophers who have not studied philosophy. On the contrary, "diplomats" who have not graduated from the same faculty and received the praise of their students will be found as they please. 


\section{SJIF Impact Factor: 6.260| ISI I.F.Value:1.241| Journal DOI: 10.36713/epra2016 \\ ISSN: 2455-7838(Online) EPRA International Journal of Research and Development (IJRD) Volume: 5 | Issue: 3 | March 2020 - Peer Reviewed Journal}

Philosophy is essentially destiny, a gift of nature or of creator. Because, his innate thinking requires clarity, intense thinking, and the ability to connect with other knowledge. In the meantime, we give the opinion of academician M.K. Mamardashvili: "If we cannot reason with absolute certainty, the devil will entertain us" [2.p.126]. In other words, when a person cannot think correctly, he is forced to accept the opinion of others and conclude that it is right. Examples are those who have gone astray and who have been influenced by extremist movements. After all, the right mindset is philosophy. As the ancient philosopher points out, a person is always persecuted by disease, animal attacks, insects, other people's anger, or by the norms they create. In other words, they are all around us. Under such circumstances, only the right person can find the right path. Philosophy encourages a person to think correctly and argues that man can only escape threats through the so-called knowledge tool. It is possible to say that in the nature of philosophical knowledge there are hidden regulators that promote human maturity and spiritual growth.

They are including:

a) Philosophical knowledge requires the learner to be well-informed and logical;

b) Philosophical knowledge is not doubtful;

c) By spiritual knowledge, spiritual changes and changes occur in a person;

d) They are the fruit of deep reflection, not superficial knowledge, but merely informing;

e) Philosophical knowledge has a different purpose, that is, the purpose of everyday knowledge.

It is important to note here that when spiritual perfection is understood as a bouquet, its best flowers are philosophical knowledge. Philosophical knowledge is at the center of its core, the core of which is the knowledge that leads to perfection. We are talking about the philosophical knowledge that lies at the heart of the complex of morals, religion, culture, history, national traditions and their interconnectedness. There is a necessary conclusion in the nature of philosophical knowledge. The researcher who gets his mentor is shaped only by his teacher's worldview and those who are close to him. This is evident in his articles and manuals. A student who has extensive knowledge will find his way. A disciple who accepts the narrow or the views of his mentor as absolute truth can only follow his teacher. It is true that anyone can follow the path of knowledge with the help of his teacher. But the reasoning is what motivates the student to set his own path, even to create. Rasul Khamzatov, a Dagestan People's Poet, says: "My father Hamzat used to come down from Tsadasa to the city by his path. I need to find my own path and not to go to the city"[3.p.43]. In the meantime, it should be noted that every person who claims to be a philosopher must have his or her own word in this world. Quoting others can be used to prove a certain point in the learning process, but in the academic work the conclusions and judgments must be made by the author. To those sitting in a meeting with Jalaluddin Rumi's friend Shamsuddin Tabrizi, "When will you speak the words that are your true essence?" [4. p.112]. He said: The curtains of the words of others are like the singers who imitate the song of others. Sports, work, and the environment, which promote the health of the human body, are the healthy ideas or philosophical knowledge that has created it. If the reader is challenged or challenged with a greater emphasis on other knowledge in his or her judgment, it is worth noting that the criterion or weight of truth in all knowledge is that of philosophical knowledge and philosophical thinking. The owner of the daily knowledge is a teacher and mentor of the past. Philosophy does not only refer to the teacher, but also to God, nature, and life. The Creator is the master of humanity with his books, his prophets, and his successors. And nature, society, and man are the great teachers God has given us. We learn from them and we grow up. That is why in his time, Jalaluddin Rumi replied: Teach us to show self! "[1. p.208]. It means that we are surrounded by a large number of teachers who are kind and loving. It is up to us to learn whether or not they can learn. Since knowledge is the basis of human perfection, it is selfish, if it does not benefit people, as it progresses toward maturity. After all, human perfection is a step of society. The purpose - the people, the purpose - the interests of society! The conditions and the peace of the country are essential for the development of philosophy. Seneca, a Roman philosopher who lived in early BC, wrote in his epistle: "The greater the burden of a traveler, the more he cares about the peace of the sea. God is thankful for Neptune for the calmness of the water. The philosopher also needs peace, and always gives thanks to the creators of peace"'[1. p.162].

\section{CONCLUSION}

The wealth of our country is peace and youth. Our young people hope to live in peace with the President of the country. It is true that one of the locomotives of our development is peace and the right path. Seneca wrote, "Philosophy does not like instability and the disintegration of word practice" [1. p.161]. Comparing the situation in our country to the neighboring countries, it is clear how true this idea is, how happy it is to be a child and a citizen of this country.

\section{REFERENCES}

1. The classical philosopher. -Tashkent: The New Generation, 2011.

2. Mamardashvili M.K. As I understand the philosophy. - Moscow: Progress, 1989

3. Hamzatov R. My Dagestan. - Tashkent: Young Guard, 1976.

4. Radish Fish. Jaloluddin Rumi. - Tashkent, 1983. 